\title{
Correction to: Carbon dynamics in cocoa agroforestry systems in Central Cameroon: afforestation of savannah as a sequestration opportunity
}

\author{
Annemarijn Nijmeijer (1) - Pierre-Éric Lauri • Jean-Michel Harmand • \\ Stéphane Saj
}

Published online: 6 February 2018

(C) Springer Science+Business Media B.V., part of Springer Nature 2018

\section{Correction to: Agroforest Syst https://doi.org/10.1007/s10457-017-0182-6}

The published on-line ms "Carbon dynamics of cocoa agroforestry systems in Central Cameroon: afforestation of savannah as a sequestration opportunity" unfortunately bears some unit errors on soil organic $\mathrm{C}$ concentration. In Table 2 as well as in the Discussion section "Soil carbon concentration dynamics in agroforests setup on savannah land", soil organic carbon (SOC) must be read in $\mathrm{g} \mathrm{kg}^{-1}$ and not in $\mathrm{mg} \mathrm{kg}^{-1}$. In Fig. 4, SOC concentration must be read read in "per mil" and not in "per cent". In Appendix 2: Raw data, some units are missing: for SOC concentration $\left(\mathrm{g} \mathrm{kg}^{-1}\right)$ and Clay concentration ("per cent").
A3 A. Nijmeijer - S. Saj

A4 CIRAD, UMR SYSTEM, 34398 Montpellier, France

A5 A. Nijmeijer $(\varangle) \cdot$ P.-É. Lauri · S. Saj $(\varangle)$

A6 SYSTEM, Univ Montpellier, INRA, CIRAD, Montpellier

A7 SupAgro, CIHEAM-IAMM, Montpellier, France

A8 e-mail: Nijmeijera@gmail.com

A9 S. Saj

A10 e-mail: stephane.saj@cirad.fr

A11 A. Nijmeijer

A12 IRAD, Département des plantes stimulantes, Yaoundé, Cameroon
A13 J.-M. Harmand

A14 CIRAD, UMR Eco\&Sols, 34398 Montpellier, France

A15 J.-M. Harmand

A16 Eco\&Sols, Univ Montpellier, CIRAD, INRA, IRD,

A17 Montpellier SupAgro, Montpellier, France

A18 J.-M. Harmand

A19 World Agroforestry Centre (ICRAF), Yaoundé, Cameroon 